\title{
PRAKTEK JUAL BELI TANAH MENURUT UU NO. 5 TAHUN 1960 UNDANGN- UNDANG POKOK AGRARIA (UUPA). \\ (STUDY DI DESA PODOREJO KEC. SUMBERGEMPOL KAB. TULUNGAGUNG)
}

\author{
ZAINURI \\ Fakultas Hukum, Universitas Wiraraja Sumenep \\ gprzainuri@yahoo.co.id
}

\begin{abstract}
ABSTRAK
Tanah merupakan bagian dari kehidupan masyarakat, bahkan bagian dari kehormatan, karena itulah tanah bukan saja dilihat dari hubungan ekonomis sebagai salah satu faktor produksi. Tetapi lebih dari itu tanah mempunyai hubungan emosional dengan masyarakat, lebih-lebih lagi masyarakat Indonesia yang agraria di mana lebih dari $60 \%$ penduduknya hidup di sekitar pertanian. Selain itu tanah sebagai ajang kehidupan dan salah satu faktor produksi yang penting, di samping harus menjamin tersedianya ruang untuk membangun sarana dan prasarana. Selain itu tanah sebagai ajang kehidupan dan salah satu faktor produksi yang penting, di samping harus menjamin tersedianya ruang untuk membangun sarana dan prasarana.
\end{abstract}

Kata Kunci : Tanah, undang undang agrarian.

\section{A. PENDAHULUAN}

Di dalam undang-undang No. 5 tahun 1960 Tentang Peraturan Dasar Pokok-Pokok Agraria. Pertama-tama dasar kenasionalan itu diletakkan dalam pasal 1 ayat 2, yang menyatakan, bahwa, "seluruh wilayah Indonesia kesatuan tanah air dari seluruh rakyat Indonesia." Pasal 1 ayat 2 menjelaskan bahwa : "seluruh bumi, air dan ruang angkasa, termasuk kekayaan alam yang terkandung di dalamnya dikuasai oleh Negara. Tanah merupakan bagian dari kehidupan masyarakat, bahkan bagian dari kehormatan, karena itulah tanah bukan saja dilihat dari hubungan ekonomis sebagai salah satu faktor produksi. Tetapi lebih dari itu tanah mempunyai hubungan emosional dengan masyarakat, lebih-lebih lagi masyarakat Indonesia yang agraria di mana lebih dari $60 \%$ penduduknya hidup di sekitar pertanian. Selain itu tanah sebagai ajang kehidupan dan salah satu faktor produksi yang penting, di samping harus menjamin tersedianya ruang untuk membangun sarana dan prasarana.

Dalam rangka hak ulayat dikenal adanya hak milik perseorangan, kiranya dapat dijelaskan bahwa dalam hukum agraria yang baru di kenal pula hak milik yang dapat dipunyai seseorang, baik sendiri maupun bersama-sama dengan orang lain atas bagian bumi, hanya permukaannya yaitu yang disebut tanah. Selain hak milik sebagai hak turuntemurun yang dapat dipunyai orang atas tanah, diadakan pula hak guna Peraturan Pemerintah Republik Indonesia No. 5 
tahun 1960 UUPA Pasal 26 Ayat 1 ditentukan bahwa: "Jual beli, penukaran, penghibahan,pemberian dan wasiat dan perbuatan-perbuatan lain yang dimaksudkan untuk peralihan hak milik serta pengawasannya diatur oleh Pemerintah,sedangkan peraturan pemerintah No.40 Tahun. 1996 tentang hak guna bangunan dan hak pakai atas tanah, pasal 34 ayat 2 dan pasal 54 ayat 3 Undang-Undang Pokok Agraria (UUPA) menjelaskan bahwa : peralihan hak guna bangunan dan hak pokok salah satunya terjadi karena jual beli”. Sedangkan pasal 34 ayat 5 menyebutkan bahwa : "jual beli yang dilakukan di hadapan notaris yang nantinya akan dibuktikan dengan akta tanah". Pada umumnya jual beli adalah menukar suatu barang dengan cara yang tertentu. Namun di dalam pasal 1457 KUUHPdt jual beli nyang obyeknya tanah, mempunyai pengertian "jual beli adalah suatu perjanjian dimana pihak yang mempunyai tanah "penjual" berjanji dan mengikatkan dirinya untuk menyerahkan hak atas tanah yang bersangkutan, kepada pihak lain yang disebut "pembeli". Sedangkan pihak pembeli berjanji dan mengikatkan diri untuk membayar harga yang telah disetujui. Dalam hukum adat "jual beli tanah" bukan perbuatan hukum jual beli tanah dalam hukum adat merupakan perbuatan pemindahan atau peralihan hak pembayaran tunai. Artinya, harga yang disetujui bersama dibayar penuh pada saat dilakukan jual beli. Sebelum membuktikan hak milik dari jual beli maka seseorang harus melakukan proses peralihan hak milik terlebih dahulu seperti yang dijelaskan dalam Undang Undang No 5 tahun 1960 pasal 23 UUPA menjelaskan bahwa: "Hak milik,demikian pula setiap peralihan,hapusnya dan pembebanannya dengan hak hak lain harus didaftarkan". Agar jual beli yang dilakukan nantinya akan mendapatkan kepastian hukum. Selanjutnya apabila tanah yang sudah berpindah kepemilikannya itu harus didaftarkan seperti ketentuan pasal 19 UU No. 5 tahun 1960 tentang pendaftaran tanah, supaya nantinya mendapatkan bukti kepemilikan dengan akta tanah.

Namun dalam realitanya masih banyak praktek jual beli tanah yang tidak sesuai dengan undang undang No.05 tahun 1960 UUPA tentang jual beli tanah. Di kabupaten Tulungagung penerapan undang undang tersebut masih sangat minim, di Kabupaten ini masih ditemukan praktek jual beli tanah yang prosedurnya tidak sesuai dengan apa yang dijelaskan dalam undang undang, salah satunya jual beli yang masih sering dilakukan adalah jual beli dibawah tangan, jual beli tanah waris, kasus seperti ini penulis temukan di Desa podorejo Kecamatan Sumbergempol. Jual beli ialah suatu perjanjian dengan mana pihak yang satu 
mengikat dirinya untuk menyerahkan suatu kebendaan, dan pihak yang lain membayar harga yang telah disepakati. Maka penulisan ini memfokuskan pada pembahasan "Praktek Jual Beli Tanah menurut UU No. 5 Tahun 1960 UndangnUndang Pokok agraria (UUPA). (Study di desa Podorejo Kec. Sumbergempol Kab. Tulungagung). Adapun yang menjadi Rumusan Masalah : Bagaimana praktek jual beli tanah di Desa Podorejo, Apa yang menjadi kendala terhadap pelaksanaan jual beli tanah di Desa Podorejo. Dan Bagaimana pemahaman Masyarakat Desa Podorejo tentang masalah jual beli tanah . Tujuan dalam Penelitian ini yaitu Untuk mengetahui bagaimana praktek jual beli tanah yang ada di Desa Podorejo, Untuk mengetahui kendala apa yang menjadi penghambat pelaksanaan jual beli. Dan Untuk mengetahui pemahaman Masyarakat tentang masalah jual beli tanah.

\section{B. PEBAHASAN}

Upaya pemerintah Indonesia untuk membentuk Hukum Agraria Nasional yang akan menggantikan Hukum Agraria Kolonial yang sesuai dengan Pancasila dan UUD 1945 sudah dimulai pada tahun 1948 dengan membentuk kepanitiaan yang diberi tugas menyusun UndangUndang Pokok Agraria, selama 12 tahun sebagai suatu rangkaian proses yang cukup panjang maka baru pada tanggal 24
September 1960 pemerintah berhasil membentuk Hukum Agraria Nasional yang dituangkan dalam Undang-Undang No 5 Tahun 1960 tentang Peraturan Dasar Pokok Agraria atau disebut dengan Undang-Undang Pokok Agraria (UUPA).

Tahapan-tahapan dalam penyusunan Undang-Undang Pokok Agraria (UUPA) dapat dijelaskan sebagai berikut :

1. Panitia Agraria Yogya Panitia ini dibentuk dengan Penetapan Presiden No. 16 Tahun 1948 tanggal 21 Mei 1948 berkedudukan di Yogjakarta dengan diketahui Satimin Reksodiharjo kepala bagian Agraria kementerian dalam negeri.

2. Panitia Agraria Jakarta Panitia Agrarian Jakarta dibubarkan dengan ketentuan Presiden No 36 Tahun 1951 Tanggal 19 Maret 1951, sekaligus dibentuk panitia Agraria Jakarta yang berkedudukan di Jakarta dan diketuai oleh Singgih Praptodiharjo, wakil Kepala bagian Agraria kementerian dalam negeri.

3. Panitia Soewahjo Berdasarkan Keputusan Presiden No 1 Tahun 1956 Tanah 14 Januari 1956 dibentuklah Panitia Negara Urusan Agraria yang berkedudukan di Jakarta dan diketuai Soewahjo Soemodilego, Sekretaris Kementerian Agraria.

4. Rancangan Soenarjo Setelah dilakukan beberapa pemilahan mengenai sistematika dan perumusan 
beberapa pasalnya, maka rancangan panitia Soewahjo diajukan oleh Menteri Agraria Soenarjo kepada Dewan Menteri pada Tanggal 14 Maret 1958.

5. Rancangan Soejarwo Berdasarkan Dekrit Presiden 5 Juli 159 kita kembali pada UUD 1945 berhubungan rancangan Soenarjo yang telah diajukan kepada DPR, beberanpa waktu lalu berdasarnkan UUDS 1950, maka dengan surat Presiden Tanggal 23 Maret 1960 rancangan tersebut ditarik kembali dan disesuaikan dengan UUD 1945.

Tujuan Penyusunan UndangUndang Pokok Agraria

a. Meletakkan dasar bagi penyusunan Hukum Agraria Nasional, yang akan merupakan alat untuk membawa kemakmuran, kebahagiaan, dan keadilan bagi Negara dan rakyat, terutama rakyat tani dalam rangka masyarakat adil dan makmur.

b. Meletakkan dasar-dasar untuk mengadakan kesatuan dan kesederhanaan dalam Hukum Pertanahan.

c. Meletakkan dasar-dasar untuk memberikan kepastian Hukum mengenai hak-hak atas tanah bagi rakyat seluruhnya.

Tujuan yang ketiga ini merupakan kebalikan dari ciri hukum Agraria juga, yaitu Hukum Agraria Koloni tidak memberikan jaminan kepastian hukum terhadap hak-hak rakyat Indonesia atas tanah dikarenakan pada waktu itu hanya hak-hak atas tanah yang tunduk pada Hukum Barat yang didaftar oleh pemerintah Hindia Belanda dengan tujuan-tujuan memberikan kepastian hukum (Rect Cadaster) sedangkan bagi tanah-tanah yang tunduk pada Hukum Adat tidak dilakukan pendaftaran tanah, kalaupun didaftarkan tujuannya bukan untuk memperoleh kepastian hukum melainkan untuk menetapkan siapa yang berkewajiban membayar pajak atas tanah.

Jual beli sudah terjadi sebelum pemerintah menetapkannya dalam undang-undang, pada zaman Rasulullah SAW pada waktu itu caranya masih primitif yaitu masih menggunakan sistem barter, tukarn menukar barang, setelah manusia memasuki abad kemajuan, mereka lalu memakai cara dan sistem penentuan harga, untuk lebih mempermudah teknis pemenuhan kebutuhannya dan menghindarkan dari kesukaran dan kesulitan.

Jual beli Tanah adalah suatu perjanjian dimana pihak yang mempunyai tanah yang disebut "Penjual", berjanji dan mengikatkan diri untuk menyerahkan haknya atas tanah yang bersangkutan kepada pihak lain, yang disebut "Pembeli" Sedangkan pihak pembeli berjanji dan 
mengikatkan untuk membayar harya yang telah disetujui yang dijual belikan menurut ketentuan Hukum Barat ini adalah apa yang disebut "tanah-tanah hak barat". Dalam Hukum Adat, "jual beli tanah" bukan perbuatan hukum yang merupakan apa yang disebut "perjanjian obligatoir". Jual beli tanah dalam Hukum Adat merupakan perbuatan hukum pemindahan hak dengan pembayaran tunai. Artinya, harga yang disetujui bersama dibayar penuh pada saat dilakukan jual beli yang bersangkutan. Dalam Hukum Adat tidak ada pengertian penyerahan yuridis sebagai pemenuhan kewajiban hukum penjual, karena justru apa yang disebut "jual beli tanah" itu adalah penyerahan hak atas tanah yang dijual kepada pembeli yang pada saat yang sama membayar penuh kepada penjual harga yang telah disetujui bersama. Maka jual beli tanah menurut pengertian Hukum Adat ini pengaturannya termasuk Hukum Tanah.

Pengertian Tanah Dalam Hukum Tanah kata sebutan "tanah" dipakai dalam arti yuridis, sebagai suatu pengertian yang telah diberi batasan resmi oleh UUPA. Dalam Pasal 4 dinyatakan, bahwa Atas dasar hak menguasai dari Negara...ditentukan adanya macam- macam hak atas permukaan bumi, yang disebut tanah, yang dapat diberikan kepada dan dipunyai oleh orang-orang... Dengan demikian jelaslah, bahwa tanah dalam pengertian yuridis adalah permukaan bumi (ayat 1). Sedang hak atas tanah adalah hak atas sebagian tertentu permukaan bumi, yang berbatas, berdimensi dua dengan ukuran panjang dan lebar.

Pengertian Hukum Tanah Tanah sebagai bagian dari bumi. Disebutkan dalam pasal 4 ayat (1) UUPA yaitu atas dasar hak menguasai dari Negara sebagai yang dimaksud dalam pasal 12 ditentukan adanya macam-macam hak atas permukaan bumi yang disebut tanah, yang dapat diberikan kepada dan dipunyai oleh orang-orang, baik sendiri maupun bersama-sama dengan orang lain, serta Badan Hukum. Dengan demikian, jelaslah bahwa tanah dalam pengertian yuridis adalah permukaan bumi, sedangkan hak atas tanah adalah hak atas sebagian tertentu permukaan bumi, yang berbatas, berdimensi dua dengan ukuran panjang dan lebar.

Dengan pendekatan pengertian hak penguasaan atas tanah sebagai, "lembaga hukum" dan "hubungan hukum konkret", nketentuan-ketentuan hukum yang mengaturnya ndapat disusun dan dipelajari dalam suatu sistematika yang khas dan masuk akal. 
Pada prinsipnya tujuan dari jual beli tanah adalah untuk peralihan hak milik atas tanah yang dijelaskan dalam pasal 23 ayat 1 UUPA,"hak milik demikian pula setiap peralihannya, hapusnya dan pembebabannya dengan hak-hak lain harus didaftarkan menurut ketentuan yang dimaksudkan dalam pasal 19 pasal 1 UUPA bahwa," kepastian hukum oleh pemerintah diadakan pendaftaran tanah di seluruh wilayah republik Indonesia menurut ketentuan-ketentuan yang diatur dengan peraturan pemerintah.

Pada prinsipnya setiap eksekusi harus dilaksanakan melalui pelelangan umum, karena dengan cara demikian diharapkan dapat diperoleh harga yang paling tinggi untuk obyek, hak tanggungan yang dijual.

Penjualan Di Bawah Tangan Secara Sukarela Penjualan di bawah ntangan yang dimaksudkan itu adalah penjualan dalam rangka eksekusi HT, yang ketentuannya terdapat dalam Pasal 20 yang mengatur Eksekusi Hak Tanggungan. Maka biarpun untuk itu diperlukan persetujuan pemberi HT, yang melakukan adalah kreditor pemegang HT.

Sistem Pendaftaran Tanah Sistem pendaftaran tanah yang dipakai di suatu Negara tergantung pada asas hukum yang dianut oleh Negara tersebut dalam mengalihkan hak atas tanahnya. Terdapat 2 macam asas hukum yaitu : "asas I'tikad baik" dan “asas nemo plus yuridis", sekalipun suatu Negara menganut salah satu asas hukum tetapi yang secara murni berpegang pada salah satu asas hokum. Asas I'tikad baik berbunyi "orang yang memperoleh suatu hak dengan I'tikad baik akan tetap menjadi pemegang hak yang sah menurut hukum. Asas ini melindungi orang yang beri'tikad baik sedangkan asas nemo plus yuridis berbunyi" orang tidak dapat mengalihkan hak melebihi hak yang ada padanya, ini berarti bahwa pengalihan hak oleh orang yang tidak berhak adalah batal. Asas ini melindungi pemegang hak yang sebenarnya. Di dalam literature hukum agraria kita kenal beberapa sistem pendaftaran tanah yakni antara lain Sistem Torrens, Sistem Positif, Sistem Negative.

\section{PENUTUP}

Jual beli tanah yang penulis temukan di desa Podorejo diantaranya adalah jual beli dibawah tangan dimana pihak yang mempunyai tanah menyerahkan tanahnya setelah pembeli membayar penuh harga yang telah disepakati, hal itu dilakukan tanpa sepengetahuan notaris desa atau aparat desa setempat. Selain itu ada praktek jual beli tanah 
warisan yang masih belum dibagi antara pewaris yang satu dengan pewaris yang lain yang pada saat itu masih di luar provinsi. Dari hasil wawancara penulis dengan salah satu warga Podorejo Rt 02/ Rw 01 bahwasannya jual beli itu terjadi apabila antara kedua belah pihak menyetujui akan perjanjian yang dilakukannya, dari situ jual beli tanah sudah dianggap syah. Praktek jual beli menurut Undang Undang No.05 Tahun 1960 adalah melakukan peralihan hak milik atas tanah dengan langkah langkah mendaftarkan tanahnya supaya mendapatkan kepastian hukum yang kuat.

Seperti yang tertuang dalam Pasal 6 Ayat 1 menjelaskan bahwa: "Jual beli, penukaran, penghibahan, pemberian dan wasiat dan perbuatan perbuatan lain yang dimaksudkan untuk peralihan hak milik serta pengwasannya diatur oleh Pemerintah. Adapun peralihan haknya diatur dalam Pasal 23 Ayat 1 menyatakan: "Hak milik, demikian pula peralihannya, hapusnya dan pembebananya atas hak hak lain harus didaftarkan menurut ketentuan Pasal 19" UUPA. Adapun dalam prakteknya tidak semua jual beli hak milik atas tanah sesuai dengan peraturan yang tertuang dalam Undang undang No, 05 Tahun 1960 tentang jual beli tanah, kenyataanya dari data yang penulis peroleh di lapangan tepatnya di Desa Podorejo Kecamatan Sumbergempol Kabupaten Tulungagung banyak praktek jual beli yang menyalahi aturan yang ada dalam Undang Undang No. 05 Tahun 1960, seperti halnya masyarakat melakukan jual beli dibawah tangan, pemindahan hak milik atas tanah tidak didaftarkan, masih adanya paksaan dari pihak lain hal ini terjadi pada jual beli tanah dari hasil warisan.

\section{DAFTAR PUSTAKA}

Menuju Penyempurnaan Hukum Tanah Nasional, Jakarta: Trisakti.Harsono, Boedi, 2003.

Hukum Agraria Indonesia, Sejarah Pembentukan UUPA dan Pelaksanaannya, Jakarta : Djambatan.

Muhammad, Abdulkadir,2004, Hukum dan Penelitian Hukum, Bandung: PT. Citra Aditya Bakti.

Raharjo, Mudjia, 2010. Desain Penelitian Kualitatif dan Contoh Proses Penelitian Kualitatif,Universitas Malang.

Sihombing, Irene Eka, 2005, Segi-Segi Hukum Tanah Dalam Pengadaan Tanah Untuk Pembangunan, Jakarta : Trisaksi.

Undang-Undang Dasar1945 Pasal 33 ayat (3)

Undang-Undang No. 5, Tahun 1960 tentang Ketentuan-ketentuan Pokok Agraria (UUPA)

PP No. 24 Tahun 1997 tentang Pendaftaran Tanah.

PP No. 37 Tahun 1998 tentang Peraturan Jabatan Pejabat Pembuat Akta Tanah (PPAT).

PMNA 3 tahun 1997 tentang Peraturan Pelaksanaan PendaftaranTanah. 